\title{
GREENHOUSE AND FIELD EVALUATION OF PHYTOREMEDIATION FOR NITROGEN AND PHOSPHORUS IN A RIPARIAN BUFFER STRIP
}

\author{
GOUDARZIAN, . $^{1 *}-$ YAZDANI, M. R. ${ }^{1}-$ MATINKHAH, S. H. ${ }^{2}$ \\ ${ }^{1}$ Department of Desertification, Faculty of Desert Studies, Semnan University, Semnan, Iran \\ (phone: +98-913-107-8249) \\ ${ }^{2}$ Department of Natural Resources, Isfahan University of Technology, Isfahan 84156-83111, Iran \\ (phone: +98-913-328-8275) \\ *Corresponding author \\ e-mail: P.goudarzian1986@gmail.com; phone: +98-938-912-3965 \\ (Received $11^{\text {th }}$ Mar 2019; accepted $19^{\text {th }}$ Jan 2021)
}

\begin{abstract}
In this research, greenhouse and field studies were conducted to evaluate the efficiency of Riparian Buffer Strips' (RBS) phytoremediation properties for N and P removal. In the field study, RBSs were investigated according to their perimeter, area, path, and length on the banks of Zayandeh-rood River, Iran. In the greenhouse study, the phytoremediation of dominant species (Fraxinus rotundifolia) and proposed species (Aianthus altissima) was investigated. The results of measurements done on the concentrations of $\mathrm{N}$ and $\mathrm{P}$ in soil showed that $\mathrm{N}$ and $\mathrm{P}$ concentrations in soil increased considerably from the beginning of the farm to the end of the farm and then sharply decreased from the beginning of the RBS to the end of it. Results revealed that in general, the efficiency of phytoremediation in removal of pollution was highest under low concentrations of pollution, lowest in average concentrations, and eventually moderate in highest concentrations ( $\mathrm{P}$ value $<0.05)$.
\end{abstract}

Keywords: arid and semi-arid basin, eutrification, hyper accumulators non-point pollutants, riparian soil

\section{Introduction}

The shortage and pollution of water are regarded as critical problems in many countries. The contamination of surface and ground waters by nitrogen $(\mathrm{N})$ and phosphorus $(\mathrm{P})$ is a major factor affecting water supplies in many parts of the world (Wang et al., 2002; Boz et al., 2013). Similarly, P is recognized as the most critical nutrient-limiting factor that can induce water pollution (Xiang et al., 2009). Regarding the dangers resulting from the increase of $\mathrm{P}$ in water, controlling its input into waters, especially rivers, is very important (Sibrell et al., 2009). High concentrations of $\mathrm{N}$ in surface waters can also lead to pollution, and in turn, to instability of the ecosystem (Hefting and Klein, 1998).

Most agricultural soil in Iran is contaminated with high doses of Nitrogen and Phosphorus due to the utilization of Urea and Triple Superphosphate over the last decades. $\mathrm{P}$ absorption is fast during initial stages but it decreases over time and eventually the $\mathrm{P}$ sediments as mineral Phosphates (with low plant absorption) (Malakouti, 2011).

Eutrification caused by $\mathrm{N}$ and $\mathrm{P}$ (Stefanidis et al., 2020) negatively affects water quality (Lin et al., 2020), the aquatic ecosystems (Lusiana et al., 2020), and the nutrient cycles (Maciej et al., 2020) resulting in a decrease in species diversity and an increase in the biomass of less desirable species (Boyd, 2020). Therefore, besides controlling the P, 
removal of $\mathrm{N}$ is also important for solving the problem of water pollution. Agricultural runoff can transport sediment, pesticides and nutrients, especially $\mathrm{N}$ and $\mathrm{P}$, to surface water and have an impact on the environment (Otto et al., 2008). Due to the evergrowing population of the world on one hand, and the gradual increase of environmental pollutions and the deterioration of agricultural land on the other, a great challenge has arisen in the field of food security, both quantitatively and qualitatively. However recently, research into the application of buffer zones has provided the grounds for the introduction of an environmentally-friendly technology to reduce the non-spot pollution in not only the soil, but also the runoff. Riparian buffer strips (RBS) are an efficient and economical way to reduce agricultural non-point source pollution (De Souza et al., 2013). The effect is usually highly satisfactory, with abatements of 70$98 \%$ for $\mathrm{P}$ and $70-95 \%$ for $\mathrm{N}$ (Borin et al., 2005; Anbumozhi et al., 2005). Phytoremediation of contaminated soils within RBS has proven to be cost effective and environmentally friendly (Wang et al., 2002). Euliss et al. (2008) assess phytoremediation for petroleum contaminants in an RBS and indicated that plants enhanced degradation of target contaminants through their phytoremediation capability. Xiang et al. (2009) suggested that phytoremediation is an effective technology for $\mathrm{N}$ and $\mathrm{P}$ removal from polluted water. In accordance with the results of Aguiar et al. (2015), buffer zones composed of woody soils were more effective in $\mathrm{P}(99.9 \%)$ and $\mathrm{N}$ (99.9\%) removal when compared to shrub (66.4\% and $83.9 \%$, respectively) or grass vegetation area (52.9\% and $61.6 \%$, respectively). Fallahi et al. (2012) showed that plant type is very important regarding the effectiveness of plant properties for phytoremediation. Taheri et al. (2014) indicated that Fraxinus rotundifolia is one of the effective species for phytoremediation. Several studies have investigated RBS effectiveness in removing suspended solids, nutrients and pesticides from agricultural runoff (Anbumozhi et al., 2005; Schilling and Jacobson, 2014; Aguiar et al., 2015) or phytoremediation for N and P (Wang et al., 2002; Xiang et al., 2009). Few studies have been done to evaluate the phytoremediation of $\mathrm{N}$ and $\mathrm{P}$ in RBS in both greenhouse and field conditions. Moreover, studies about them are limited in Middle Eastern countries. Therefore, this research was done with the aim of assessing the use of phytoremediation to reduce $\mathrm{N} \& \mathrm{P}$ contaminants in both greenhouse and RBS. In addition to contaminant quantification, the cumulative effect of roots was evaluated over the 6-month study period.

\section{Materials and methods}

\section{Study timeline}

The overall timeline of the current study includes five stages and covers a period of two years (24 months) from Mar. 2016 to Feb. 2018. These stages include Buffer Zone sampling and analysis of the RBZs data (Field Study - Mar. to Aug. 2016), Greenhouse Preparation and Deployment phase (3 months - Sep. 2016 to Nov. 2017), Greenhouse Study phase (6 months - Des. to May. 2017), Database Lock (3 months - Jun. to Aug. 2017), and finally, Data Analysis and Report (6 months - Sep. 2017 to Feb. 2018).

\section{Field study}

The Zayandeh-Rood River in center of Iran, one of the most polluted sites in this region is an example of the anthropogenic impacts on the environment in the last four 
decades that have proven to be extremely deleterious due to the rapid development of agriculture (Sanayei et al., 2009). The semi-arid Zayandeh-Rood River Basin is one of the most strategic and important river basins of Iran (Madani and Marino, 2009). This river basin, with an area of $41,347 \mathrm{~km}^{2}$, is located between the $50^{\circ} 24^{\prime}$ to $53^{\circ} 24^{\prime}$ longitudes and $31^{\circ} 11^{\prime}$ to $33^{\circ} 42^{\prime}$ latitudes (Fig. 1).

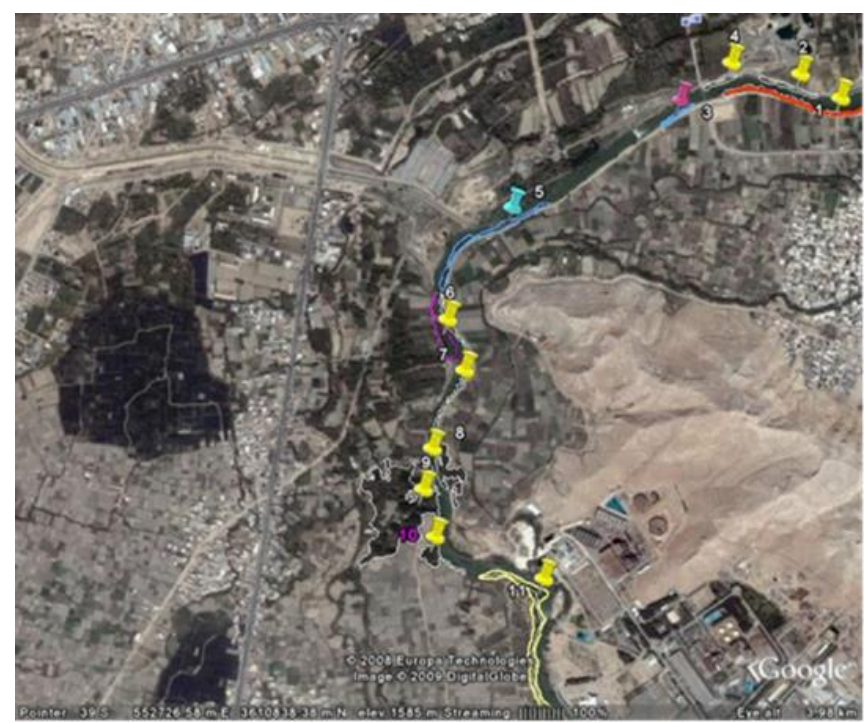

Figure 1. Buffer zone plots along agricultural land around Zayandeh-Rood-The route with the highest Concentration

The Zayandeh-Rood River Basin covers an area of about $26,917 \mathrm{~km}^{2}$ in central Iran. The main traditional staple crops of the basin are wheat, rice, barley, and corn, which are highly water consumptive and polluting. Zayandeh-Rood River, with an average flow of 1400 million $\mathrm{m}^{3}$, including 650 million $\mathrm{m}^{3}$ of natural flow and 750 million $\mathrm{m}^{3}$ of transferred flow, is the main surface water resource of the basin (Gohari et al., 2013). Table 1 summarizes some of the main characteristics of this basin.

Table 1. General characterizes of the Zayandeh-rood basin (Gohari et al., 2013)

\begin{tabular}{c|c}
\hline Attribute & Value \\
\hline Physiographic and hydrologic & \\
Elevation range (m) & $1470-3974$ \\
Annual average precipitation range (mm) & $50-1500$ \\
Average temperature range $\left({ }^{\circ} \mathrm{C}\right)$ & $3-30$ \\
Annual potential evapotranspiration $(\mathrm{mm})$ & 1500 \\
Average humidity (\%) & $24-57$ \\
River length (Km) & 350 \\
Average natural flow (MCM) & 650 \\
Average transferred flow (MCM) & 750 \\
Agricultural & $34-42$ \\
Irrigation efficiency (\%) & 73 \\
Agricultural water use (\%) & 270,000 \\
Irrigated area (ha) & 30,000 \\
Rain fed area (ha) &
\end{tabular}


The river water is used for drinking, industrial and agricultural purposes. In its westeast journey, Zayandeh-Rood River passes several agricultural areas (Gohari et al., 2013). The determination of pollutants throughout the river is important and has a great role in controlling the ecological condition of this body of water. The first step was finding appropriate fields with agricultural lands that are adjacent to RBS along river through field studies, using remote sensing (RS) and data analysis. The area and perimeter of agricultural land was then determined and analyzed. The Polygon centers were determined with a "place mark" and then coordinates were calculated. One buffer zone site was selected for our study.

As agricultural application is the biggest source of non-point pollution on the national scale, samples were collected along 3 parallel transects from the beginning to the end of the farm and beginning to the end of the buffer zone at the depth of $30 \mathrm{~cm}$ and then analyzed in laboratory for $\mathrm{N}$ and $\mathrm{P}$ concentrations. Species biometrics were investigated in the field. Results are shown in Table 2. Two of the fast growing and drought-contamination resistant species, the rich "Fraxinus rotundifolia Mill" and also the newly proposed "Aianthus altissima", were evaluated in the greenhouse study (Taheri et al., 2014; Li et al., 2015; Yang et al., 2015).

Table 2. Biometrics of tree species at plot 9

\begin{tabular}{c|c|c|c|c|c}
\hline Dominant species & Family & $\begin{array}{c}\text { Average diameter } \\
\text { at breast } \mathbf{( c m})\end{array}$ & $\begin{array}{c}\text { Average height } \\
(\mathbf{m})\end{array}$ & $\begin{array}{c}\text { Diameter standard } \\
\text { deviation }(\mathbf{c m})\end{array}$ & $\begin{array}{c}\text { Height standard } \\
\text { deviation }(\mathbf{m})\end{array}$ \\
\hline Fraxinus rotundifolia Mill & Oleaceae & 20.15 & 11.25 & 2.68 & 0.79 \\
Salix alba L. & Salicaceae & 29.45 & 10.55 & 2.4 & 0.91 \\
Elaeagnus angustifolia L. & Elaeagnaceae & 18.80 & 9.37 & 1.50 & 1.51 \\
Populus nigra L & Salicaceae & 19.10 & 17.00 & 1.01 & 1.01 \\
Morus alba L. & Moraceae & 19.85 & 12.50 & 1.10 & 1.45 \\
\hline
\end{tabular}

\section{Greenhouse evaluation}

At first, in order to design the greenhouse study, 30 canals were inserted into soil $(50 \mathrm{~cm} \times 50 \mathrm{~cm} \times 2 \mathrm{~m})$. In order to avoid water loss, a plastic layer and then a half tube and finally another plastic layer were placed in the soil (Diagram 1). Next, an experiment was conducted with ash (Fraxinus rotundifolia Mill) as the dominant species in the region, and Heaven tree (Aianthus altissima) as the proposed species. Potassium nitrate and Potassium phosphate solutions were used to create concentrations of 5, 10 and $50 \mathrm{mg} \mathrm{L}^{-1}$. To move the water from the beginning to the end of the canal, a slope of $5 \%$ was created. Three replicates were included for statistical validity. During early March, 40 young seedlings of Fraxinus rotundifolia and 40 young seedlings of Aianthus altissima were planted in the canals, so that four plants were placed in each canal to assess cumulative effect of the roots. A total of 10 canals were left un-vegetated as control to consider the role of soil in remediation. To decrease evaporation, soil surface was coated with sand and aluminum foil. Irrigation was done with pure water at the rate of twice per week; after being planted 3 months, plants were irrigated with polluted water. After being planted 4 months (in late spring), water was collected at the end of the canals and the concentrations of $\mathrm{N}$ and $\mathrm{P}$ were determined in laboratory. One month later, the collected water was circulated in canals and the concentrations of $\mathrm{N}$ and $\mathrm{P}$ were again determined in laboratory. Finally, after 6 months, the circulated water was again collected and the pollution was determined in laboratory. Therefore, sampling was 
done in three stages. Total P (inorganic and organic) was determined by oxidation of unfiltered samples with potassium persulfate, and analyzing at $885 \mathrm{~nm}$ wavelength on the spectrophotometer upon color development with an ammonium molybdate-ascorbic acid-antimony method (Genchi, 1990). Total N (inorganic and organic) was determined in unfiltered samples by oxidation with potassium persulfate (Genchi, 1990) upon color development with the salicylic acid method; samples were analyzed at 410-nm wavelength on the spectrophotometer (spectrophotometer UV-Vis- Camspec M350 Double Beam) (Cataldo et al., 1975).

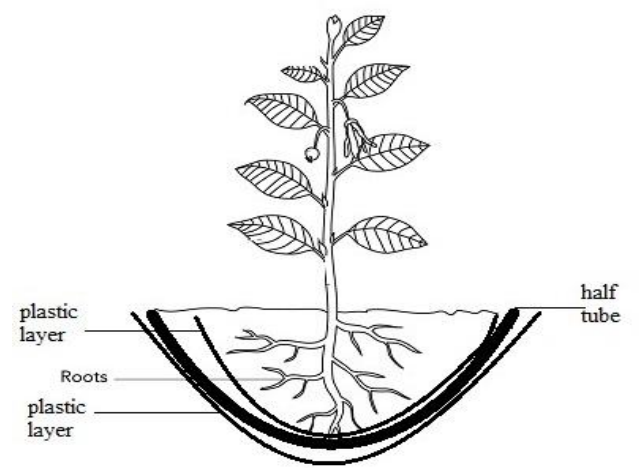

Diagram 1. Canal design to avoid water loss

\section{Statistical analysis}

Analysis of the results was done using IBM SPSS version 21. A two-way analysis of variance was conducted to explore the effect of the species and the concentration levels on the reduction of the contamination of $\mathrm{N}$ and $\mathrm{P}$. The concentration levels were presented as $5 \mathrm{mg} / \mathrm{L}, 10 \mathrm{mg} / \mathrm{L}$, and $50 \mathrm{mg} / \mathrm{L}$. Based on the results from the initial analysis, multiple one-way ANOVA tests (with Tukey HSD as the Post-hoc test) were conducted to compare the $\mathrm{N}$ and $\mathrm{P}$ reductions for each concentration level and at different times for each of the species. Homogeneity of Variance was tested using Levene's Test of Equality of Error Variances.

\section{Results}

\section{Field evaluation}

The total length of Zayande-rood River from Zardkuhe Bakhtiari to Gavkhuni marsh is estimated to be $461.65 \mathrm{Km}$. The distribution of RBSs in Zayandeh-rood basin with measurements of perimeter, area, length, latitude and longitude along agricultural land are given in Appendix A. Coordinates of the starting and the end point of the path are $\left(32.5447^{\circ}\right.$ and $\left.51.519^{\circ}\right)$ and $\left(32.6237^{\circ}\right.$ and $\left.51.722^{\circ}\right)$, respectively. The largest area of buffer zone is at plot 9 (32.6298 and 51.5614) and the smallest area of buffer zone is at plot 26 (32.5895 and 51.5449). Moreover, the greatest length is located at plot 39 (32.438 and 51.5838) and the shortest length is attributed to plot 41 (32.6416 and 51.5775). Furthermore, the largest perimeter of buffer zone is at plot 33 (32.5731 and 51.5231) and the smallest perimeter is at plot 30 (32.5866 and 51.5375).

The results of measuring the concentrations of $\mathrm{N}$ and $\mathrm{P}$ in the field RBS with a width of $10 \mathrm{~m}$ at plot 9 revealed that the highest concentrations of $\mathrm{N}$ and $\mathrm{P}$ are related to the 
end of the farm and the lowest concentrations are related to the end of the buffer zone. $\mathrm{N}$ and $\mathrm{P}$ concentrations in soil increased considerably from the beginning of the farm to the end of the farm and then sharply decreased from the beginning of the buffer zone to the end of it, as average concentrations of $\mathrm{N}$ and $\mathrm{P}$ dropped from $0.33 \mathrm{mg} \mathrm{L}^{-1}$ to $0.035 \mathrm{mg} \mathrm{L}^{-1}$ and from $6.97 \mathrm{mg} \mathrm{L}^{-1}$ to $1.74 \mathrm{mg} \mathrm{L}^{-1}$, respectively (Fig. 2a, b).

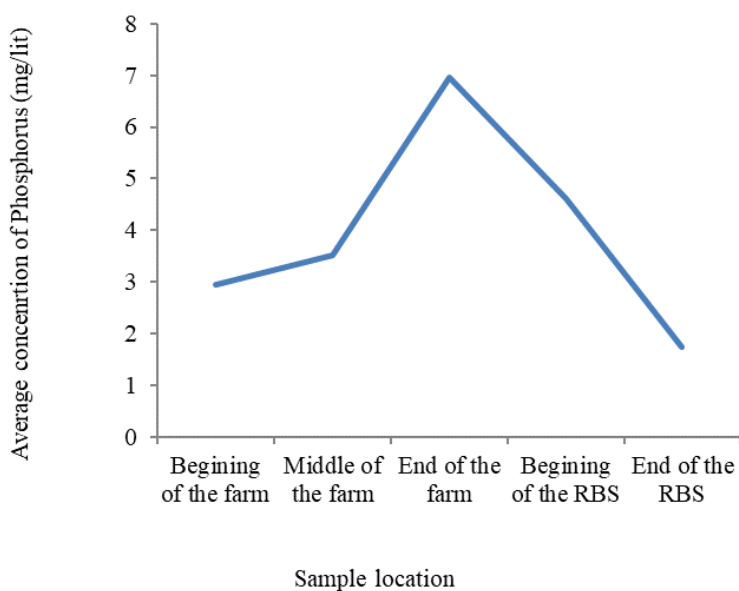

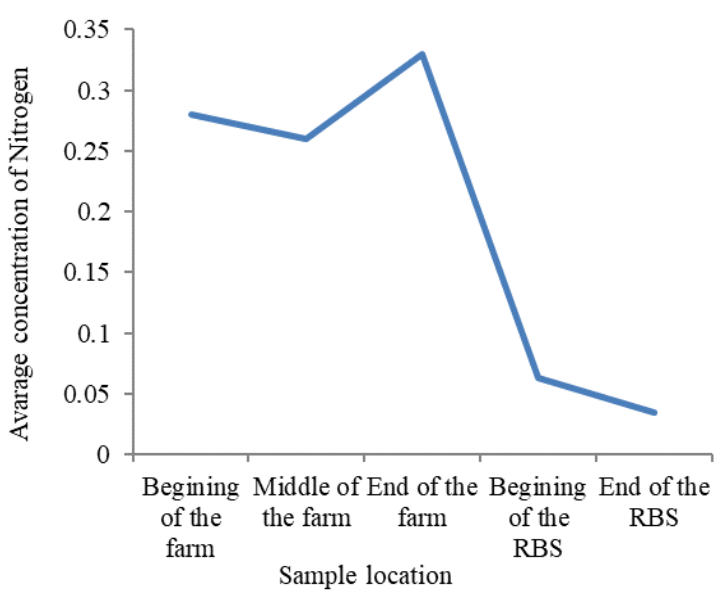

b

Figure 2. Alterations in average concentration of $P(a)$ and $N(b)$ in the farm and the RBS

According to the results of the Tukey Test presented in Table 3, the changes in the concentration of $\mathrm{N}$ from the beginning to the end of the farm is significant $(\mathrm{p}<0.05)$, and the same applies to the concentration of $\mathrm{P}(\mathrm{p}<0.05)$. Likewise, the concentrations of $\mathrm{N}$ and $\mathrm{P}$ contaminants decrease significantly from the beginning to the end of the RBS ( $p<0.05$ for both).

Table 3. Multiple comparison of field RBS nitrogen and phosphorus by Tukey HSD

\begin{tabular}{|c|c|c|c|c|c|c|}
\hline \multicolumn{7}{|c|}{ Dependent variable: nitrogen } \\
\hline \multicolumn{7}{|c|}{ Tukey HSD } \\
\hline \multirow{2}{*}{ (I) Point } & \multirow{2}{*}{ (J) Point } & \multirow{2}{*}{$\begin{array}{c}\text { Mean difference } \\
\text { (I-J) }\end{array}$} & \multirow{2}{*}{ Std. error } & \multirow{2}{*}{ Sig. } & \multicolumn{2}{|c|}{$95 \%$ confidence interval } \\
\hline & & & & & Lower bound & Upper bound \\
\hline \multirow{4}{*}{ Beginning of the farm } & Middle of the farm & -.45833 & .567240 & .925 & -2.15573 & 1.23906 \\
\hline & End of the farm & $-2.51000^{*}$ & .567240 & .002 & -4.20739 & -.81261 \\
\hline & Beginning of the RBS & -.45000 & .567240 & .930 & -2.14739 & 1.24739 \\
\hline & End of the RBS & 1.10500 & .567240 & .326 & -.59239 & 2.80239 \\
\hline \multirow{4}{*}{ Middle of the farm } & Beginning of the farm & .45833 & .567240 & .925 & -1.23906 & 2.15573 \\
\hline & End of the farm & $-2.05167^{*}$ & .567240 & .013 & -3.74906 & -.35427 \\
\hline & Beginning of the RBS & .00833 & .567240 & 1.000 & -1.68906 & 1.70573 \\
\hline & End of the RBS & 1.56333 & .567240 & .080 & -.13406 & 3.26073 \\
\hline \multirow{4}{*}{ End of the farm } & Beginning of the farm & $2.51000^{*}$ & .567240 & .002 & .81261 & 4.20739 \\
\hline & Middle of the farm & $2.05167^{*}$ & .567240 & .013 & .35427 & 3.74906 \\
\hline & Beginning of the RBS & $2.06000^{*}$ & .567240 & .013 & .36261 & 3.75739 \\
\hline & End of the RBS & $3.61500^{*}$ & .567240 & .000 & 1.91761 & 5.31239 \\
\hline \multirow{4}{*}{ Beginning of the RBS } & Beginning of the farm & .45000 & .567240 & .930 & -1.24739 & 2.14739 \\
\hline & Middle of the farm & -.00833 & .567240 & 1.000 & -1.70573 & 1.68906 \\
\hline & End of the farm & $-2.06000^{*}$ & .567240 & .013 & -3.75739 & -.36261 \\
\hline & End of the RBS & 1.55500 & .567240 & .083 & -.14239 & 3.25239 \\
\hline
\end{tabular}




\begin{tabular}{|c|c|c|c|c|c|c|}
\hline \multirow{4}{*}{ End of the RBS } & Beginning of the farm & -1.10500 & .567240 & .326 & -2.80239 & .59239 \\
\hline & Middle of the farm & -1.56333 & .567240 & .080 & -3.26073 & .13406 \\
\hline & End of the farm & $-3.61500^{*}$ & .567240 & .000 & -5.31239 & -1.91761 \\
\hline & Beginning of the RBS & -1.55500 & .567240 & .083 & -3.25239 & .14239 \\
\hline \multicolumn{7}{|c|}{ Dependent variable: phosphorus } \\
\hline \multirow{4}{*}{ Beginning of the farm } & Middle of the farm & .12167 & .057171 & .247 & -.04941 & .29274 \\
\hline & End of the farm & $-.33333^{*}$ & .057171 & .000 & -.50441 & -.16226 \\
\hline & Beginning of the RBS & $.22833^{*}$ & .057171 & .006 & .05726 & .39941 \\
\hline & End of the RBS & $.28250^{*}$ & .057171 & .001 & .11142 & .45358 \\
\hline \multirow{4}{*}{ Middle of the farm } & Beginning of the farm & -.12167 & .057171 & .247 & -.29274 & .04941 \\
\hline & End of the farm & $-.45500^{*}$ & .057171 & .000 & -.62608 & -.28392 \\
\hline & Beginning of the RBS & .10667 & .057171 & .366 & -.06441 & .27774 \\
\hline & End of the RBS & .16083 & .057171 & .072 & -.01024 & .33191 \\
\hline \multirow{4}{*}{ End of the farm } & Beginning of the farm & $.33333^{*}$ & .057171 & .000 & .16226 & .50441 \\
\hline & Middle of the farm & $.45500^{*}$ & .057171 & .000 & .28392 & .62608 \\
\hline & Beginning of the RBS & $.56167^{*}$ & .057171 & .000 & .39059 & .73274 \\
\hline & End of the RBS & $.61583^{*}$ & .057171 & .000 & .44476 & .78691 \\
\hline \multirow{4}{*}{ Beginning of the RBS } & Beginning of the farm & $-.22833^{*}$ & .057171 & .006 & -.39941 & -.05726 \\
\hline & Middle of the farm & -.10667 & .057171 & .366 & -.27774 & .06441 \\
\hline & End of the farm & $-.56167^{*}$ & .057171 & .000 & -.73274 & -.39059 \\
\hline & End of the RBS & .05417 & .057171 & .875 & -.11691 & .22524 \\
\hline \multirow{4}{*}{ End of the RBS } & Beginning of the farm & $-.28250^{*}$ & .057171 & .001 & -.45358 & -.11142 \\
\hline & Middle of the farm & -.16083 & .057171 & .072 & -.33191 & .01024 \\
\hline & End of the farm & $-.61583^{*}$ & .057171 & .000 & -.78691 & -.44476 \\
\hline & Beginning of the RBS & -.05417 & .057171 & .875 & -.22524 & .11691 \\
\hline
\end{tabular}

\section{Greenhouse evaluation (model experiment)}

Figure 3 shows the comparison of phytoremediation between Fraxinus rotundifolia and Aianthus altissima for $\mathrm{N}$ and $\mathrm{P}$. According to Tables 4 and 5, efficiency of trees in removal of pollution is the highest in lowest concentrations of pollution, the lowest in average concentration, and finally medium in the highest pollution concentration $(\mathrm{P}$ value $<0.05$ for both). Figures 4 and 5 show phytoremediation of each species separately and Descriptive Statistics of $\mathrm{N}$ and $\mathrm{P}$ removal by each species in each time period are given in Appendices $D, E, F, G$.

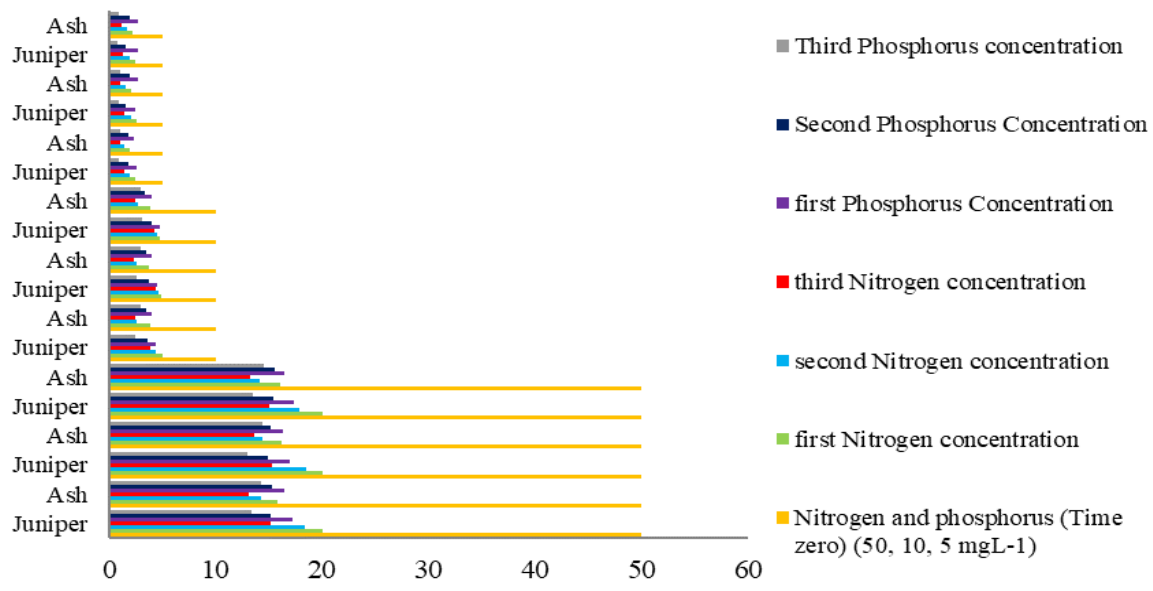

Figure 3. Comparison of phytoremediation between Fraxinus rotundifolia and Aianthus altissima for $N$ and $P$ in three time periods 
Table 4. Multiple comparison of Aianthus altissima nitrogen and phosphorus concentration by Tukey HSD

\begin{tabular}{|c|c|c|c|c|c|c|}
\hline \multicolumn{7}{|c|}{ Dependent variable: nitrogen } \\
\hline \multirow{2}{*}{ (I) Concentration } & \multirow{2}{*}{ (J) Concentration } & \multirow{2}{*}{$\begin{array}{c}\text { Mean } \\
\text { difference (I-J) }\end{array}$} & \multirow{2}{*}{ Std. error } & \multirow{2}{*}{ Sig. } & \multicolumn{2}{|c|}{$95 \%$ confidence interval } \\
\hline & & & & & Lower bound & Upper bound \\
\hline \multirow{2}{*}{$50 \mathrm{mg} / \mathrm{L}$} & $10 \mathrm{mg} / \mathrm{L}$ & $13.3055^{*}$ & .08107 & .000 & 13.0986 & 13.5124 \\
\hline & $5 \mathrm{mg} / \mathrm{L}$ & $15.8724^{*}$ & .08107 & .000 & 15.6655 & 16.0793 \\
\hline \multirow{2}{*}{$10 \mathrm{mg} / \mathrm{L}$} & $50 \mathrm{mg} / \mathrm{L}$ & $-13.3055^{*}$ & .08107 & .000 & -13.5124 & -13.0986 \\
\hline & $5 \mathrm{mg} / \mathrm{L}$ & $2.5669^{*}$ & .08107 & .000 & 2.3600 & 2.7738 \\
\hline \multirow{2}{*}{$5 \mathrm{mg} / \mathrm{L}$} & $50 \mathrm{mg} / \mathrm{L}$ & $-15.8724^{*}$ & .08107 & .000 & -16.0793 & -15.6655 \\
\hline & $10 \mathrm{mg} / \mathrm{L}$ & $-2.5669^{*}$ & .08107 & .000 & -2.7738 & -2.3600 \\
\hline \multicolumn{7}{|c|}{ Dependent variable: phosphorus } \\
\hline \multirow{2}{*}{$50 \mathrm{mg} / \mathrm{L}$} & $10 \mathrm{mg} / \mathrm{L}$ & $11.5133^{*}$ & .09789 & .000 & 11.2635 & 11.7632 \\
\hline & $5 \mathrm{mg} / \mathrm{L}$ & $13.5178^{*}$ & .09789 & .000 & 13.2680 & 13.7676 \\
\hline \multirow{2}{*}{$10 \mathrm{mg} / \mathrm{L}$} & $50 \mathrm{mg} / \mathrm{L}$ & $-11.5133^{*}$ & .09789 & .000 & -11.7632 & -11.2635 \\
\hline & $5 \mathrm{mg} / \mathrm{L}$ & $2.0044^{*}$ & .09789 & .000 & 1.7546 & 2.2543 \\
\hline \multirow{2}{*}{$5 \mathrm{mg} / \mathrm{L}$} & $50 \mathrm{mg} / \mathrm{L}$ & $-13.5178^{*}$ & .09789 & .000 & -13.7676 & -13.2680 \\
\hline & $10 \mathrm{mg} / \mathrm{L}$ & $-2.0044^{*}$ & .09789 & .000 & -2.2543 & -1.7546 \\
\hline
\end{tabular}

Table 5. Multiple comparison of Fraxinus rotundifolia nitrogen and phosphorus concentration by Tukey HSD

\begin{tabular}{|c|c|c|c|c|c|c|}
\hline \multicolumn{7}{|c|}{ Dependent variable: nitrogen } \\
\hline \multirow{2}{*}{ (I) Concentration } & \multirow{2}{*}{ (J) Concentration } & \multirow{2}{*}{$\begin{array}{c}\text { Mean } \\
\text { difference (I-J) }\end{array}$} & \multirow{2}{*}{ Std. error } & \multirow{2}{*}{ Sig. } & \multicolumn{2}{|c|}{$95 \%$ confidence interval } \\
\hline & & & & & Lower bound & Upper bound \\
\hline \multirow{2}{*}{$50 \mathrm{mg} / \mathrm{L}$} & $10 \mathrm{mg} / \mathrm{L}$ & $11.5535^{*}$ & .05792 & .000 & 11.4057 & 11.7013 \\
\hline & $5 \mathrm{mg} / \mathrm{L}$ & $12.9469^{*}$ & .05792 & .000 & 12.7991 & 13.0948 \\
\hline \multirow{2}{*}{$10 \mathrm{mg} / \mathrm{L}$} & $50 \mathrm{mg} / \mathrm{L}$ & $-11.5535^{*}$ & .05792 & .000 & -11.7013 & -11.4057 \\
\hline & $5 \mathrm{mg} / \mathrm{L}$ & $1.3935^{*}$ & .05792 & .000 & 1.2456 & 1.5413 \\
\hline \multirow{2}{*}{$5 \mathrm{mg} / \mathrm{L}$} & $50 \mathrm{mg} / \mathrm{L}$ & $-12.9469^{*}$ & .05792 & .000 & -13.0948 & -12.7991 \\
\hline & $10 \mathrm{mg} / \mathrm{L}$ & $-1.3935^{*}$ & .05792 & .000 & -1.5413 & -1.2456 \\
\hline \multicolumn{7}{|c|}{ Dependent variable: phosphorus } \\
\hline \multirow{2}{*}{$50 \mathrm{mg} / \mathrm{L}$} & $10 \mathrm{mg} / \mathrm{L}$ & $11.9049^{*}$ & .04847 & .000 & 11.7812 & 12.0286 \\
\hline & $5 \mathrm{mg} / \mathrm{L}$ & $13.5380^{*}$ & .04847 & .000 & 13.4143 & 13.6617 \\
\hline \multirow{2}{*}{$10 \mathrm{mg} / \mathrm{L}$} & $50 \mathrm{mg} / \mathrm{L}$ & $-11.9049^{*}$ & .04847 & .000 & -12.0286 & -11.7812 \\
\hline & $5 \mathrm{mg} / \mathrm{L}$ & $1.6331^{*}$ & .04847 & .000 & 1.5094 & 1.7568 \\
\hline \multirow{2}{*}{$5 \mathrm{mg} / \mathrm{L}$} & $50 \mathrm{mg} / \mathrm{L}$ & $-13.5380^{*}$ & .04847 & .000 & -13.6617 & -13.4143 \\
\hline & $10 \mathrm{mg} / \mathrm{L}$ & $-1.6331^{*}$ & .04847 & .000 & -1.7568 & -1.5094 \\
\hline
\end{tabular}

Statistical comparison of the two species (using factorial two-way ANOVA) reveals a significant difference in both $\mathrm{N}$ and $\mathrm{P}$ concentration reduction between the species (Table 6). Considering the homogeneity of Variance (Levene's Test of Equality of Error Variances), it is necessary to perform separate one-way ANOVAs with Tukey HSD as the Post-hoc test to compare the $\mathrm{N}$ and $\mathrm{P}$ reductions for the different concentration levels and at different times for each of the species. 


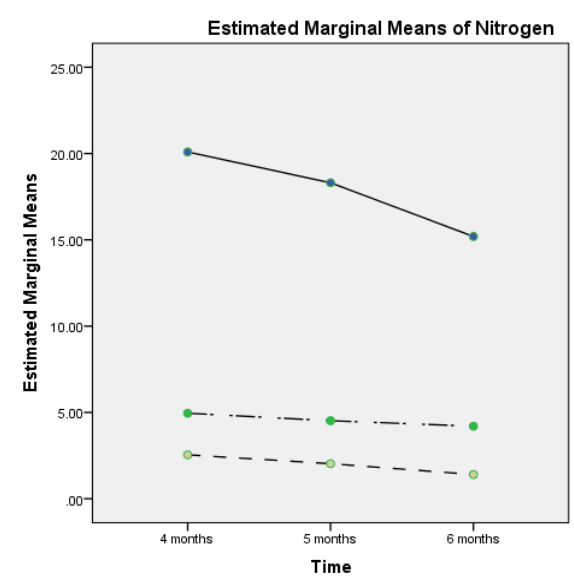

a

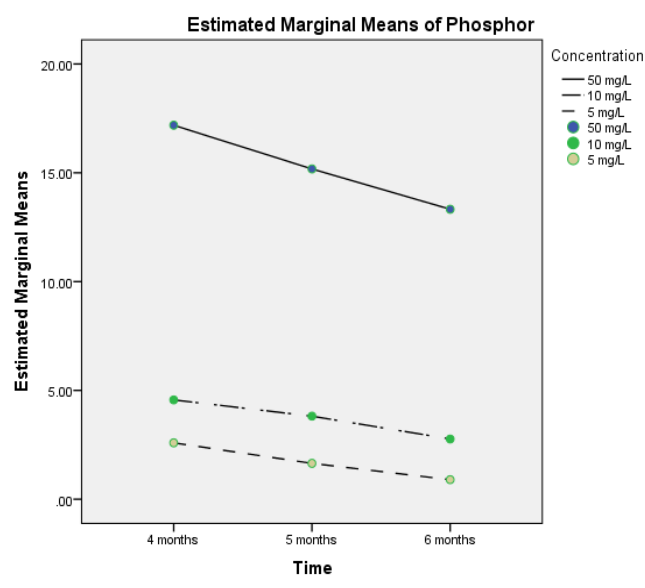

b

Figure 4. $N(a)$ and $P(b)$ removal by Aianthus altissima in three time periods

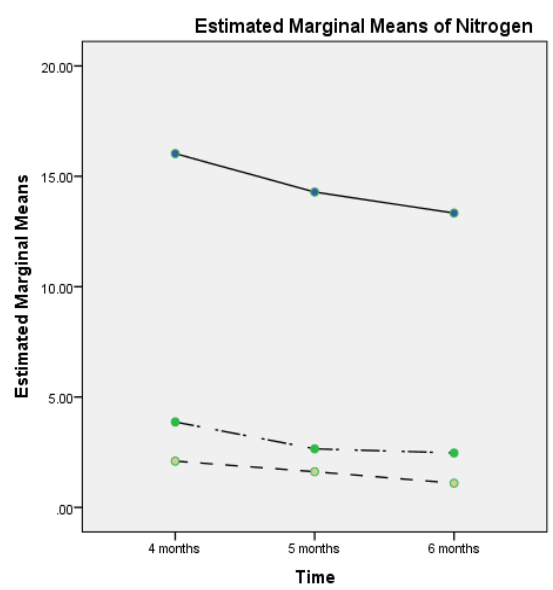

a

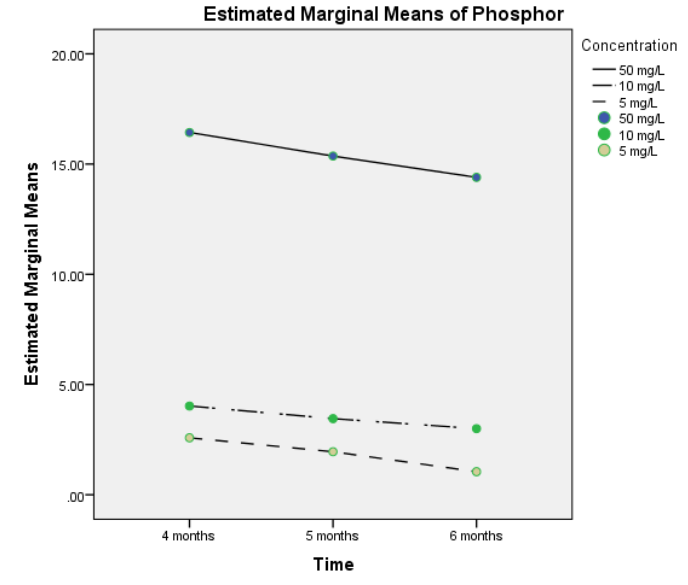

b

Figure 5. $N(a)$ and $P(b)$ removal by Fraxinus rotundifolia in three time periods

Results from the follow-up one-way ANOVAs show that the highest $\mathrm{N}$ reduction occurs at the early stage (i.e. 4 months) and much lesser reduction occurs in the second and third stages (i.e. 5 and 6 months, respectively), as $\mathrm{N}$ reduction in Aianthus altissima and Fraxinus rotundifolia is about $60 \%$ and $68 \%$ at the first, and then reaches to almost $63 \%$ and $71 \%$ at the second, eventually reaching $69 \%$ and $74 \%$ at the third stage, respectively ( $\mathrm{P}$ value $<0.05$ ) (Tables 7 and 8 ). Similarly, $\mathrm{P}$ declines sharply at the early stage and reduction in the second and third stages are much lesser, whereas $\mathrm{P}$ reduction in Aianthus altissima and Fraxinus rotundifolia is about $65 \%$ and $67 \%$ at first and then reaches to almost $70 \%$ and $69 \%$ at the second and $74 \%$ and $71 \%$ at the third stages, respectively ( $\mathrm{P}$ value $<0.05$ ) (Tables 7 and 8 ). It seems that Fraxinus rotundifolia is more effective in $\mathrm{N}$ reduction than Aianthus altissima, and vice versa, $\mathrm{P}$ declines more than $\mathrm{N}$ in Aianthus altissima $(\mathrm{P}$ value $<0.05)$. $\mathrm{P}$ reduction in Fraxinus rotundifolia is almost equivalent to the reduction of $\mathrm{N}$ (a little more) (Tables 7 and 8$)(\mathrm{P}$ value $<0.05)$. 
Table 6. Tests of between-subjects effects for the two-way ANOVA-Aianthus altissima and Fraxinus rotundifolia

\begin{tabular}{|c|c|c|c|c|c|c|}
\hline \multicolumn{7}{|c|}{ Dependent variable: nitrogen } \\
\hline Source & $\begin{array}{c}\text { Type III sum of } \\
\text { squares }\end{array}$ & df & Mean square & $\mathbf{F}$ & Sig. & $\begin{array}{l}\text { Partial eta } \\
\text { squared }\end{array}$ \\
\hline Corrected MODEL & $777.985^{b}$ & 5 & 155.597 & 6264.251 & .000 & 1.000 \\
\hline Intercept & 942.359 & 1 & 942.359 & 37938.845 & .000 & 1.000 \\
\hline Type & 19.845 & 1 & 19.845 & 798.949 & .000 & .985 \\
\hline Concentration & 748.262 & 2 & 374.131 & 15062.301 & .000 & 1.000 \\
\hline Type $*$ concentration & 9.879 & 2 & 4.939 & 198.852 & .000 & .971 \\
\hline Error & .298 & 12 & .025 & & & \\
\hline Total & 1720.642 & 18 & & & & \\
\hline Corrected total & 778.283 & 17 & & & & \\
\hline \multicolumn{7}{|c|}{ Dependent variable: phosphorus } \\
\hline Corrected model & $725.008^{b}$ & 5 & 145.002 & 5926.186 & .000 & 1.000 \\
\hline Intercept & 1122.527 & 1 & 1122.527 & 45877.453 & .000 & 1.000 \\
\hline Type & .842 & 1 & .842 & 34.429 & .000 & .742 \\
\hline Concentration & 723.722 & 2 & 361.861 & 14789.197 & .000 & 1.000 \\
\hline Type $*$ concentration & .443 & 2 & .222 & 9.055 & .004 & .601 \\
\hline Error & .294 & 12 & .024 & & & \\
\hline Total & 1847.829 & 18 & & & & \\
\hline Corrected total & 725.302 & 17 & & & & \\
\hline
\end{tabular}

${ }^{\text {a Time }}=4$ months

${ }^{\mathrm{b}} \mathrm{R}$ squared $=1.000($ Adjusted $\mathrm{R}$ squared $=.999)$

Table 7. Multiple comparison of. Aianthus altissima nitrogen and phosphorus time by Tukey $H S D$

\begin{tabular}{|c|c|c|c|c|c|c|}
\hline \multicolumn{7}{|c|}{ Dependent variable: nitrogen } \\
\hline \multirow{2}{*}{ (I) Time } & \multirow{2}{*}{ (J) Time } & \multirow{2}{*}{$\begin{array}{c}\text { Mean difference } \\
(\mathbf{I}-\mathbf{J})\end{array}$} & \multirow{2}{*}{ Std. error } & \multirow{2}{*}{ Sig. } & \multicolumn{2}{|c|}{$95 \%$ confidence interval } \\
\hline & & & & & Lower bound & Upper bound \\
\hline \multirow{2}{*}{4 months } & 5 months & $.9100^{*}$ & .08107 & .000 & .7031 & 1.1169 \\
\hline & 6 months & $2.2645^{*}$ & .08107 & .000 & 2.0576 & 2.4714 \\
\hline \multirow{2}{*}{5 months } & 4 months & $-.9100^{*}$ & .08107 & .000 & -1.1169 & -.7031 \\
\hline & 6 months & $1.3544^{*}$ & .08107 & .000 & 1.1475 & 1.5613 \\
\hline \multirow{2}{*}{6 months } & 4 months & $-2.2645^{*}$ & .08107 & .000 & -2.4714 & -2.0576 \\
\hline & 5 months & $-1.3544^{*}$ & .08107 & .000 & -1.5613 & -1.1475 \\
\hline \multicolumn{7}{|c|}{ Dependent variable: phosphorus } \\
\hline \multirow{2}{*}{4 months } & 5 months & $1.2333^{*}$ & .09789 & .000 & .9835 & 1.4832 \\
\hline & 6 months & $2.4511^{*}$ & .09789 & .000 & 2.2013 & 2.7009 \\
\hline \multirow{2}{*}{5 months } & 4 months & $-1.2333^{*}$ & .09789 & .000 & -1.4832 & -.9835 \\
\hline & 6 months & $1.2178^{*}$ & .09789 & .000 & .9680 & 1.4676 \\
\hline \multirow{2}{*}{6 months } & 4 months & $-2.4511^{*}$ & .09789 & .000 & -2.7009 & -2.2013 \\
\hline & 5 months & $-1.2178^{*}$ & .09789 & .000 & -1.4676 & -.9680 \\
\hline
\end{tabular}


Table 8. Multiple comparison of Fraxinus rotundifolia nitrogen and phosphorus time by Tukey HSD

\begin{tabular}{|c|c|c|c|c|c|c|}
\hline \multicolumn{7}{|c|}{ Dependent variable: nitrogen } \\
\hline \multirow{2}{*}{ (I) Time } & \multirow{2}{*}{ (J) Time } & \multirow{2}{*}{$\begin{array}{c}\text { Mean difference } \\
(\mathbf{I}-\mathbf{J})\end{array}$} & \multirow{2}{*}{ Std. error } & \multirow{2}{*}{ Sig. } & \multicolumn{2}{|c|}{$95 \%$ confidence interval } \\
\hline & & & & & Lower bound & Upper bound \\
\hline \multirow{2}{*}{4 months } & 5 months & $1.1461^{*}$ & .05792 & .000 & .9983 & 1.2939 \\
\hline & 6 months & $1.6993^{*}$ & .05792 & .000 & 1.5515 & 1.8472 \\
\hline \multirow{2}{*}{5 months } & 4 months & $-1.1461^{*}$ & .05792 & .000 & -1.2939 & -.9983 \\
\hline & 6 months & $.5532^{*}$ & .05792 & .000 & .4054 & .7010 \\
\hline \multirow{2}{*}{6 months } & 4 months & $-1.6993^{*}$ & .05792 & .000 & -1.8472 & -1.5515 \\
\hline & 5 months & $-.5532^{*}$ & .05792 & .000 & -.7010 & -.4054 \\
\hline \multicolumn{7}{|c|}{ Dependent variable: phosphorus } \\
\hline \multirow{2}{*}{4 months } & 5 months & $.7584^{*}$ & .04847 & .000 & .6347 & .8822 \\
\hline & 6 months & $1.5331^{*}$ & .04847 & .000 & 1.4094 & 1.6568 \\
\hline \multirow{2}{*}{5 months } & 4 months & $-.7584^{*}$ & .04847 & .000 & -.8822 & -.6347 \\
\hline & 6 months & $.7747^{*}$ & .04847 & .000 & .6510 & .8984 \\
\hline \multirow{2}{*}{6 months } & 4 months & $-1.5331^{*}$ & .04847 & .000 & -1.6568 & -1.4094 \\
\hline & 5 months & $-.7747^{*}$ & .04847 & .000 & -.8984 & -.6510 \\
\hline
\end{tabular}

In addition, results revealed that soil has an important role in $\mathrm{N}$ and $\mathrm{P}$ reduction (Fig. 6). Canals without trees indicate significant reduction. Generally, $\mathrm{P}$ reduction is about $32 \%$ and $\mathrm{N}$ reduction is about 30\% (Appendices $F$ and $G)(\mathrm{P}$ value $<0.05$ ). It seems that $\mathrm{P}$ is more available than $\mathrm{N}$ in soil (Tables 9 and 10), which could be related to stronger $\mathrm{P}$ bonds than those of $\mathrm{N}$ with soil clay particles as well as little movement of $\mathrm{P}$ through soil clay particles.

Table 9. Multiple comparison of soil nitrogen and phosphorus time by Tukey HSD

\begin{tabular}{|c|c|c|c|c|c|c|}
\hline \multicolumn{7}{|c|}{ Dependent variable: nitrogen } \\
\hline \multirow{2}{*}{ (I) Time } & \multirow{2}{*}{ (J) Time } & \multirow{2}{*}{$\begin{array}{c}\text { Mean difference } \\
(\mathbf{I}-\mathbf{J})\end{array}$} & \multirow{2}{*}{ Std. Error } & \multirow{2}{*}{ Sig. } & \multicolumn{2}{|c|}{$95 \%$ confidence interval } \\
\hline & & & & & Lower bound & Upper bound \\
\hline \multirow{2}{*}{4 months } & 5 months & $1.5343^{*}$ & .14963 & .000 & 1.1524 & 1.9161 \\
\hline & 6 months & $2.7576^{*}$ & .14963 & .000 & 2.3757 & 3.1395 \\
\hline \multirow{2}{*}{5 months } & 4 months & $-1.5343^{*}$ & .14963 & .000 & -1.9161 & -1.1524 \\
\hline & 6 months & $1.2233^{*}$ & .14963 & .000 & .8415 & 1.6052 \\
\hline \multirow{2}{*}{6 months } & 4 months & $-2.7576^{*}$ & .14963 & .000 & -3.1395 & -2.3757 \\
\hline & 5 months & $-1.2233^{*}$ & .14963 & .000 & -1.6052 & -.8415 \\
\hline \multicolumn{7}{|c|}{ Dependent variable: phosphorus } \\
\hline \multirow{2}{*}{4 months } & 5 months & $1.4822^{*}$ & .17440 & .000 & 1.0371 & 1.9273 \\
\hline & 6 months & $2.9422^{*}$ & .17440 & .000 & 2.4971 & 3.3873 \\
\hline \multirow{2}{*}{5 months } & 4 months & $-1.4822^{*}$ & .17440 & .000 & -1.9273 & -1.0371 \\
\hline & 6 months & $1.4600^{*}$ & .17440 & .000 & 1.0149 & 1.9051 \\
\hline \multirow{2}{*}{6 months } & 4 months & $-2.9422^{*}$ & .17440 & .000 & -3.3873 & -2.4971 \\
\hline & 5 months & $-1.4600^{*}$ & .17440 & .000 & -1.9051 & -1.0149 \\
\hline
\end{tabular}


Table 10. Multiple comparisons of soil nitrogen and phosphorus concentration by Tukey $H S D$

\begin{tabular}{|c|c|c|c|c|c|c|}
\hline \multicolumn{7}{|c|}{ Dependent variable: nitrogen } \\
\hline \multicolumn{7}{|c|}{ Tukey HSD } \\
\hline \multirow{2}{*}{ (I) Concentration } & \multirow{2}{*}{ (J) Concentration } & \multirow{2}{*}{$\begin{array}{c}\text { Mean } \\
\text { difference }(I-J)\end{array}$} & \multirow{2}{*}{ Std. error } & \multirow{2}{*}{ Sig. } & \multicolumn{2}{|c|}{$95 \%$ confidence interval } \\
\hline & & & & & Lower bound & Upper bound \\
\hline \multirow{2}{*}{$50 \mathrm{mg} / \mathrm{L}$} & $10 \mathrm{mg} / \mathrm{L}$ & $30.2731^{*}$ & .14963 & .000 & 29.8912 & 30.6549 \\
\hline & $5 \mathrm{mg} / \mathrm{L}$ & $33.5341^{*}$ & .14963 & .000 & 33.1522 & 33.9160 \\
\hline \multirow{2}{*}{$10 \mathrm{mg} / \mathrm{L}$} & $50 \mathrm{mg} / \mathrm{L}$ & $-30.2731^{*}$ & .14963 & .000 & -30.6549 & -29.8912 \\
\hline & $5 \mathrm{mg} / \mathrm{L}$ & $3.2610^{*}$ & .14963 & .000 & 2.8792 & 3.6429 \\
\hline \multirow{2}{*}{$5 \mathrm{mg} / \mathrm{L}$} & $50 \mathrm{mg} / \mathrm{L}$ & $-33.5341^{*}$ & .14963 & .000 & -33.9160 & -33.1522 \\
\hline & $10 \mathrm{mg} / \mathrm{L}$ & $-3.2610^{*}$ & .14963 & .000 & -3.6429 & -2.8792 \\
\hline \multicolumn{7}{|c|}{ Dependent variable: phosphorus } \\
\hline \multirow{2}{*}{$50 \mathrm{mg} / \mathrm{L}$} & $10 \mathrm{mg} / \mathrm{L}$ & $30.7044^{*}$ & .17440 & .000 & 30.2593 & 31.1495 \\
\hline & $5 \mathrm{mg} / \mathrm{L}$ & $33.2800^{*}$ & .17440 & .000 & 32.8349 & 33.7251 \\
\hline \multirow{2}{*}{$10 \mathrm{mg} / \mathrm{L}$} & $50 \mathrm{mg} / \mathrm{L}$ & $-30.7044^{*}$ & .17440 & .000 & -31.1495 & -30.2593 \\
\hline & $5 \mathrm{mg} / \mathrm{L}$ & $2.5756^{*}$ & .17440 & .000 & 2.1305 & 3.0207 \\
\hline \multirow{2}{*}{$5 \mathrm{mg} / \mathrm{L}$} & $50 \mathrm{mg} / \mathrm{L}$ & $-33.2800^{*}$ & .17440 & .000 & -33.7251 & -32.8349 \\
\hline & $10 \mathrm{mg} / \mathrm{L}$ & $-2.5756^{*}$ & .17440 & .000 & -3.0207 & -2.1305 \\
\hline
\end{tabular}
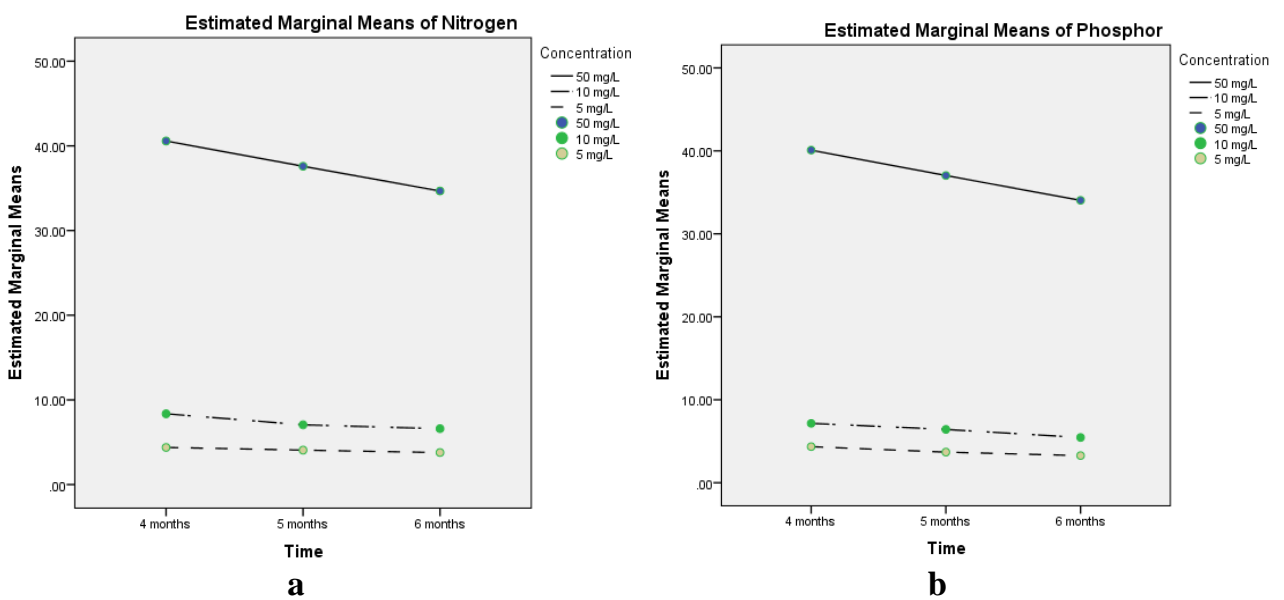

Figure 6. $N(a)$ and $P(b)$ removal by soil in three time periods

\section{Discussion}

Medium to long term monitoring is necessary to fully understand environmental sustainability and efficiency of RBSs. Therefore, measurements of perimeter, area, length, latitude and longitude of RBS plots along agricultural land on the banks of Zayandeh-rood River are such a helpful tool for future studies and for understanding the RBS efficiency. In this research, our focus was on plot 9 as it encompasses the largest area of buffer zone (total area $=4.3 \mathrm{ha}$ ). Results in this plot suggest that $\mathrm{N}$ and $\mathrm{P}$ removal occurs through an RBS. RBS seems to be more efficient in removal of $\mathrm{P}$ compared to N. Generally, results obtained from the RBS showed that N and P were accumulated from the beginning to the end of the farm, as there was a $0.12 \%$ increase per meter for $\mathrm{N}$ and a $0.50 \%$ increase per meter for $\mathrm{P}$. Subsequently, at the beginning of 
the root system in the mentioned trees in the RBS, a $1.38 \%$ reduction per meter for $\mathrm{N}$ concentration and a $0.59 \%$ reduction per meter for $\mathrm{P}$ concentration were observed at the beginning of the RBS. Eventually, due to the final completion of phytoremediation and the integral effect of root system in the trees in the RBS, a $0.3 \%$ reduction in $\mathrm{N}$ concentration and a $1.47 \%$ reduction in $\mathrm{P}$ concentration were measured at the end of the RBS.

It should be noted that significant reductions of these two pollutants can be due to the composition of ash, willow, poplar, buckthorn and mulberry, based on their effective phytoremediation properties (Table 2). Woody vegetation has deep rooting systems and is more effective in $\mathrm{P}$ and $\mathrm{N}$ removal than shrubs and grass areas (Aguiar et al., 2015). They have a significant energy advantage over grassy plants (Glibovytska et al., 2019). They cover broader surface and volume of soil that make them able to accumulate higher amounts of pollutant in their bigger organs. Additionally, tree species are suggested as the most affordable vegetation type for phytoremediation with profounder root system, being appropriate to be planted in less fertile sites with a frail structure and a higher rate of transpiration (Haroni et al., 2019). The costs of phytoremediation would be reduced if other regarded vegetation are replaced with tree species (EPA, 2000). The ability of a RBS to remove $\mathrm{N}$ and $\mathrm{P}$ from water or soil is influenced by the type and quantity of existing vegetation and by soil condition (Mikkelsen and Vesho, 2000; Wang et al., 2002) Indeed, the effectiveness of phytoremediation is also affected by different contamination levels of wastewater (Assif and Saeed, 2020).

Previous studies of $\mathrm{N}$ and $\mathrm{P}$ attenuation in RBSs have indicated that they reduce suspended soil particulates considerably (Schilling and Jacobson, 2014; Aguiar et al., 2015) because of their flatter slopes and high surface roughness and in doing so, they often reduce $\mathrm{P}$ concentrations in streams (Mikkelsen and Vesho, 2000).

Since the greatest reduction occurs after 4 months, it could be concluded that phytoremediation is very active in early spring, and that after this period, the trees' capacity will decrease. Perhaps, it is because the root system achieves its highest function in this time period. According to Mali et al. (2019) growth stage significantly influenced the nutrient uptake, and during the winter dormant period, plant uptake is generally very low or nonexistent in RBSs (Haycock and Pinay, 1993). Groffman et al. (1992) showed that plant uptake was the dominant sink for $\mathrm{N}$ during growing season in RBSs. Ebrahimi et al., 2019 showed that Plant species and the growth season influence the efficiency of plant uptake that is associated with root systems properties.

According to the results obtained from soil, it is suggested that soil has an important role in $\mathrm{N}$ and $\mathrm{P}$ reduction, as well. Boz et al. (2013) claimed that soil microbial community composition and activity could be affected by suitable manipulation of the environment they live in. If correctly applied, such an approach could become a very effective way to remediate excess of chemicals. Furthermore, we could suggest that in this regard, tree root systems could provide macro-pores and create rapid inflow routes which will be used for transmission of $\mathrm{N}$ and $\mathrm{P}$ into the soil profile. Therefore, it could decrease the efficiency of Phytoremediation. Another possible explanation for the effectiveness of the root system in these two species, as they are necessarily mycorrhizal, is that the Arbuscular Mycorrhizal fungi have boosted the uptake of the $\mathrm{N}$ and $\mathrm{P}$ contaminants through the roots. According to (Bücking and Kafle, 2015), mycorrhizal fungi play a crucial role in the uptake of nutrients, such as phosphate and nitrate, in many plant species. This means that this $\mathrm{N}$ and $\mathrm{P}$ contaminant removal could have been improved by the mycorrhizal fungi and through the roots of the species 
studied here. Mycorrhizal fungi could have affected the results of the current study in yet another way. According to (Kebrabadi et al., 2014), the highest colonization percentage of mycorrhizal fungi is in spring, which corresponds with the timing of this current study. The findings of the current study revealed that the highest rate of contaminant reduction was in early spring, which corresponds with the results of (Kebrabadi et al., 2014; Mali et al., 2019). According to the results of the current study, Aianthus altissima was more efficient than Fraxinus rotundifolia in reduction of $\mathrm{P}$ (Li et al., 2015; Yang et al., 2015), and as stated in Taheri et al. (2014), Fraxinus rotundifolia is an effective species for phytoremediation of $\mathrm{N}$. Thus, combining these two species can be more helpful to remove excess $\mathrm{N}$ and $\mathrm{P}$ and avoid water eutrophication.

Systematic evaluation of the greenhouse studies conducted based on the results from the field study suggests that RBZs with emphasis on the phytoremediation applications are beneficial environmentally friendly technique with the potential to rectify the contamination issue due to the eutrification caused by the agricultural runoff. Therefore, investigating the existing plant species in RBZs to determine species with higher phytoremediation capabilities, and the utilization of such results in the design of the RBZs, is of prime importance to future studies. Utilization of phytoremediation properties in buffer zones necessitates the integration of the results from background studies with agricultural skills and technique. Successful contamination remediation programs can be achieved through correct integration of the field conditions and the planting of the proper species to increase the access of the plant to the contamination, which in turn, emphasizes the need for bilateral field and greenhouse studies.

\section{Conclusion}

According to the results of the current study, when runoff passes through the buffer zone, $\mathrm{P}$ and $\mathrm{N}$ contaminations decrease significantly. Generally, the average $\mathrm{N}$ and $\mathrm{P}$ contamination reaches its highest levels at the end of the farm and the beginning of the RBS; however, the average contamination falls down to its minimum by the end of the RBS, which proved our first hypothesis, stating that RBSs are effective tools to reduce $\mathrm{N}$ and $\mathrm{P}$ contamination. As a result, we can conclude that the best approach to prevent the non-spot contamination is to create RBSs on the banks of rivers and other water resources which are vulnerable to contamination. The results of the current study revealed that an RBS, based on phytoremediation properties, may be a helpful and friendly technique to deal with the problem of agricultural runoff pollution in the process of purifying eutrophicated water.

Moreover, the findings of the current study revealed that, as Aguiar et al. (2015), Lou et al. (2017) and Seo et al. (2017) claimed, plants with deep root systems, like Fraxinus rotundifolia and Aianthus altissima are more effective in reducing $\mathrm{N}$ and $\mathrm{P}$ contaminants and Mixed cultivation can enhance the effects of phytoremediation. Due to the existing inter-species differences in phytoremediation of different contamination, biofilters using a mixture of plants are proposed (Irga et al., 2019).

Therefore, it is concluded that in creating RBSs for the purpose of contaminant removal, combining the two species of Fraxinus rotundifolia and Aianthus altissima could be an ideal and will result in effective removal of $\mathrm{N}$ and $\mathrm{P}$ contaminants. It is worth mentioning that Fraxinus rotundifolia is one of the most common species in this region and numerous ecological and geographical ranges are allocated to it. Moreover, it is available and inexpensive and, as the results of the current study also showed, has 
effective properties in remediation of $\mathrm{N}$ and $\mathrm{P}$. Noteworthy, Aianthus altissima is a species which is resistant to drought and pollution, so it could be considered as an applicable species to be planted in RBSs.

\section{Recommendations for further research}

The selection of appropriate plants for phytoremediation is an open field for study, as different combinations of woody plants with deep root systems could have different effects on $\mathrm{N}$ and $\mathrm{P}$ contaminant removal. In our current study, we examined the beneficial effect of two species of woody plants which were commonplace to the region. However, examining the $\mathrm{N}$ and $\mathrm{P}$ contaminant reduction capability of other woody species can be subject to further research.

Another area for research could be the investigation of the role of mycorrhizae fungi on the reduction or removal of $\mathrm{N}$ and $\mathrm{P}$ contaminants. The findings of this study revealed that there might be a close direct relationship between the mycorrhizae activity and the reduction of the $\mathrm{N}$ and $\mathrm{P}$ contaminants.

\section{REFERENCES}

[1] Aguiar Jr, T. R., Raseraa, K., Parronc, L. M., Britod, A. G., Ferreira, M. T. (2015): Nutrient removal effectiveness by riparian buffer zones in rural temperate watersheds: the impact of no-till crops practices. - Agricultural Water Management 149: 74-80.

[2] Anbumozhi, V., Radhakrishnan, J., Yamaji, E. (2005): Impact of riparian buffer zones on water quality and associated management considerations. - Ecological Engineering 24: 517-523.

[3] Asif, M., Saeed, S. (2020): Study of Effectiveness of phytoremediation at different contamination level of wastewater. - Hydrol Current Research 11(314): 1-5.

[4] Borin, M., Vianello, M., Morari, F., Zanin, G. (2005): Effectiveness of buffer strips in removing pollutants in runoff from a cultivated field in North-East Italy. - Agriculture. Ecosystems and Environment 105: 101-114.

[5] Boyd, C. E. (2020): Eutrophication (chapter 15). - In: Water Quality. Springer, Cham, Switzerland, pp. 311-322.

[6] Boz, B., Rahman, M., Bottegal, M., Basaglia, M., Squartini, A., Gumiero, B., Casella, S. (2013): Vegetation, soil and hydrology management influence denitrification activity and the composition of nirK-type denitrifier communities in a newly afforested riparian buffer. - New Biotechnology 6: 675-684.

[7] Bücking, H., Kafle, A. (2015): Role of arbuscular mycorrhizal fungi in the nitrogen uptake of plants: current knowledge and research gaps. - Agronomy 5(4): 587-612.

[8] Cataldo, D. A., Haroon, M., Schrader, L. E., Youngs, V. L. (1975): Rapid colorimetric determination of nitrate in plant tissue by nitration of salicylic acid. - Communications in Soil Science and Plant Analysis 6: 71-80.

[9] De Souza, A. L. T., Fonseca, D. G., Liborio, R. A., Tanaka, M. O. (2013): Influence of riparian vegetation and forest structure on the water quality of rural low-order streams in SE Brazil. - Forest Ecology and Management 298: 12-18.

[10] Ebrahimi, N., Stoddard, F. L., Hartikainen, H., Seppänen, M. M. (2019): Plant species and growing season weather influence the efficiency of selenium biofortification. Nutrient Cycling in Agroecosystems 114(2): 111-124.

[11] EPA (2000): Guidelines for Preparing Economic Analyses. EPA 240- R-00-003. - US Environmental Protection Agency, Washington, DC. 
[12] Euliss, K., Ho, C., Schwab, A. P., Rock, S., Banks, N. K. (2008): Greenhouse and field assessment of phytoremediation for petroleum contaminants in a riparian zone. Bioresource Technology 99: 1961-1971.

[13] Fallahi, F., Ayati, B., Ganjidoust, H. (2011): Lab scale study of $\mathrm{n}$ removal by phytoremediation. - Journal of Water \& Wastewater 1: 57-65. (In Persian).

[14] Genchi, G. (1990): Azoto e fosforo totali. - Nova Thalassia 11: 171-179 (in Italian).

[15] Glibovytska, N. I., Karavanovych, K. B., Kachala, T. B. (2019): Prospects of phytoremediation and phytoindication of oil-contaminated soils with the help of energy plants. - Journal of Ecological Engineering 20(7): 147-154.

[16] Gohari, A., Eslamian, S., Mirchi, A., Abedi-Koupaei, J., Massah Bavani, A., Madani, K. (2013): Water transfer as a solution to water shortage: a fix that can Backfire. - Journal of Hydrology 491: 23-39.

[17] Groffman, P. M., Arthur, J. G., Simmons, R. C. (1992): Nitrate dynamics in riparian forests; microbial studies. - Journal of Environmental Quality 21: 666-671.

[18] Haroni, N. N., Badehian, Z., Zarafshar, M., Bazot, S. (2019): The effect of oil sludge contamination on morphological and physiological characteristics of some tree species. Ecotoxicology 28(5): 507-519.

[19] Haycock, N. E., Pinay, G. (1993): Groundwater nitrate dynamics in grass and poplar vegetated riparian buffer strips during the winter. - Journal of Environmental Quality 22: 273-278.

[20] Hefting, M. M., Jeroen de Klein, J. M. (1998): N removal in Buffer strips along a lowland stream in the Netherlands: a pilot study. - Environmental Pollution 102: 521-526.

[21] Irga, P. J., Pettit, T., Irga, R. F., Paull, N. J., Douglas, A. N., Torpy, F. R. (2019): Does plant species selection in functional active green walls influence VOC phytoremediation efficiency? - Environmental Science and Pollution Research 26(13): 12851-12858.

[22] Kebrabadi, B. Z., Daryayi, M. G., Matinizadeh, M., Salehi, A. (2014): Investigation and identification of mycorrhizal symbiosis in rhizosphere ash (Fraxinus rotundifolia). Bulletin of Environment, Pharmacology and Life Sciences 3: 43-48.

[23] Li, Y., Chen, C., Wen, K., Li, G., Cao, P., Zhang, Y., Tackett, T. M. (2015): Abandoned reverse osmosis membrane effects on phytoremediation of saline soils with trees. Ecological Engineering 84: 660-667.

[24] Lin, S. S., Shen, S. L., Zhou, A., Lyu, H. M. (2020): Assessment and management of lake eutrophication: a case study in Lake Erhai, China. - Science of The Total Environment 751. https://doi.org/10.1016/j.scitotenv.2020.141618.

[25] Lou, J., Qi, S., Peng, L., Xie, X. (2017): Enhanced phytoremediation capacity of a mixedspecies plantation of Eucalyptus globulus and Chickpeas. - Geochemical Exploration 182: 201-205.

[26] Lusiana, E. D., Buwono, N. R., Mahmudi, M., Noviasari, P. P. (2020): Nutrient limit estimation for eutrophication modelling at Sengguruh Reservoir, Malang, Indonesia. Nature Environment and Pollution Technology 19: 361-365.

[27] Maciej, K., Piotr, Z., Magdalena, G., Jolanta, E. K., Joanna, K., Irina, F. (2020): Effect of eutrophication and humification on nutrient cycles and transfer efficiency of matter in freshwater food webs. - Hydrobiologia 847: 2521-2540.

[28] Madani, K., Mariño, M. A. (2009): System dynamics analysis for managing Iran's Zayandeh-Rud river basin. - Water Resour Manage 23: 2163-2187.

[29] Malakouti, M. (2011): Relationship between balanced fertilization and healthy agricultural products (a review). - Journal of Crop and Weed Ecophysiology 4(16): 133-150.

[30] Mali, S. S., Naik, S. K., Jha, B. K., Singh, A. K., Bhatt, B. P. (2019): Planting geometry and growth stage linked fertigation patterns: impact on yield, nutrient uptake and water productivity of Chilli pepper in hot and sub-humid climate. - Scientia Horticulturae 249: 289-298.

[31] Mikkelsen, K., Vesho, L. (2000): Riparian Soils: A Literature Review. - Center for Streamside Studies, University of Washington Water Center, Washington. 
[32] Otto, S., Vianello, M., Infantino, A., Zanin, G., Di Guardo, A. (2008): Effect of a fullgrown vegetative filter strip on herbicide runoff: maintaining of filter capacity over time. - Chemosphere 71: 74-82.

[33] Sanayei, Y., Ismail, N., Talebi, S. M. (2009): Determination of heavy metals in Zayandeh Rood River, Isfahan-Iran. - World Applied Sciences Journal 6: 1209-1214.

[34] Schilling, K. E., Jacobson, P. (2014): Effectiveness of natural riparian buffers to reduce subsurface nutrient losses to incised streams. - Catena 114: 140-148.

[35] Seo, B. H., Kim, H. S., Kuppusamy, S., Kim, K. H., Kim, K. R. (2017): Enhanced nitrogen and phosphorus removal by woody plants with deep-planting technique for the potential environmental management of carcass burial sites. - Sustainability 9(1): 155.

[36] Sibrell, P. L., Montgomery, G. A., Ritenour, K. L., Tucker, T. W. (2009): Removal of pus from agricultural wastewaters using adsorption media prepared from acid mine drainage sludge. - Water Research 43: 2240-2250.

[37] Stefanidis, K., Christopoulou, A., Poulos, S., Dassenakis, E., Dimitriou, E. (2020): Nitrogen and phosphorus loads in Greek rivers: implications for management in compliance with the water framework directive. - Water 12: 1-18.

[38] Taheri, M., Madadi, R., Jafari, S., Mortazavi, N. (2014): Evaluation some ornamental species cultivated in Tehran, in terms of refining ability heavy metals from soil. International Journal of Biosciences 9: 26-33.

[39] Wang, Q., Cui, Y., Dong, Y. (2002): Phytoremediation of polluted waters potentials and prospects of wetland plants. - Acta Biotechnologica 22: 199-208.

[40] Xiang, W., Yang, X. E., Zed, R. (2009): Phytoremediation facilitates removal of N and P from eutrophicated water and release from sediment. - Environmental Monitoring and Assessment 157: 277-285.

[41] Yang, Y., Liang, Y., Ghosh, A., Song, Y., Chen, H., Tang, M. (2015): Assessment of arbuscular mycorrhizal fungi status and heavy metal accumulation characteristics of tree species in a lead-zinc mine area: potential applications for phytoremediation. Environmental Science and Pollution Research 22(17): 13179-13193.

\section{APPENDIX}

Appendix A. Distribution of RBS in Zayandeh-rood basin with measurements of perimeter, area, length, latitude, and longitude along agricultural land

\begin{tabular}{c|c|c|c|c|c}
\hline Plot number & Perimeter $(\mathbf{K m})$ & Area $(\mathbf{H a})$ & Path length $(\mathbf{K m})$ & Latitude & Longitude \\
\hline 1 & $0 / 99$ & $0 / 5$ & $0 / 48$ & $32 / 6414$ & $51 / 5758$ \\
2 & $0 / 45$ & $0 / 18$ & $0 / 19$ & $32 / 6421$ & $51 / 5744$ \\
3 & $0 / 29$ & $0 / 07$ & $0 / 13$ & $32 / 6413$ & $51 / 5702$ \\
4 & $0 / 24$ & $0 / 11$ & $0 / 11$ & $32 / 6424$ & $51 / 572$ \\
5 & $0 / 98$ & $0 / 52$ & $0 / 48$ & $32 / 6381$ & $51 / 5644$ \\
6 & $0 / 6$ & $0 / 54$ & $0 / 27$ & $32 / 6348$ & $51 / 5622$ \\
7 & $0 / 46$ & $0 / 24$ & $0 / 22$ & $32 / 6333$ & $51 / 5628$ \\
8 & $0 / 22$ & $0 / 09$ & $0 / 1$ & $32 / 631$ & $51 / 5617$ \\
9 & $1 / 47$ & $4 / 31$ & $0 / 28$ & $32 / 6298$ & $51 / 5614$ \\
10 & $0 / 47$ & $0 / 36$ & $0 / 16 /$ & $32 / 6334$ & $51 / 5628$ \\
11 & $2 / 19$ & $2 / 04$ & $0 / 94$ & $32 / 6272$ & $51 / 5656$ \\
12 & $0 / 63$ & $0 / 56$ & $0 / 3$ & $32 / 6206$ & $51 / 5672$ \\
13 & $0 / 68$ & $0 / 89$ & $0 / 2$ & $32 / 6198$ & $51 / 5665$ \\
14 & $0 / 74$ & $1 / 6$ & $0 / 29$ & $32 / 6108$ & $51 / 5668$ \\
15 & $0 / 4$ & $0 / 38$ & $0 / 16$ & $32 / 6091$ & $51 / 5661$ \\
16 & $0 / 21$ & $0 / 28$ & $0 / 16$ & $32 / 6077$ & $51 / 5664$ \\
17 & $0 / 88$ & $0 / 61$ & $0 / 19$ & $32 / 6064$ & $51 / 5661$
\end{tabular}




\begin{tabular}{|c|c|c|c|c|c|}
\hline 18 & $3 / 17$ & $3 / 84$ & $1 / 38$ & $32 / 5963$ & $51 / 5645$ \\
\hline 19 & $0 / 51$ & $0 / 24$ & $0 / 24$ & $32 / 5977$ & $51 / 5653$ \\
\hline 20 & $0 / 51$ & $0 / 25$ & $0 / 24$ & $32 / 5952$ & $51 / 5599$ \\
\hline 21 & $0 / 72$ & $0 / 27$ & $0 / 36$ & $32 / 5942$ & $51 / 5596$ \\
\hline 22 & $0 / 6$ & $0 / 26$ & $0 / 27$ & $32 / 5937$ & $51 / 5554$ \\
\hline 23 & $0 / 52$ & $0 / 17$ & $0 / 25$ & $32 / 5903$ & $51 / 5252$ \\
\hline 24 & $0 / 82$ & $0 / 24$ & $0 / 4$ & $32 / 5895$ & $51 / 5486$ \\
\hline 25 & $0 / 21$ & $0 / 14$ & $0 / 15$ & $32 / 5889$ & $51 / 5459$ \\
\hline 26 & $0 / 19$ & $0 / 05$ & 0/09 & $32 / 5895$ & $51 / 5449$ \\
\hline 27 & $0 / 5$ & $0 / 24$ & $0 / 19$ & $32 / 5902$ & $51 / 5422$ \\
\hline 28 & $0 / 45$ & $0 / 22$ & $0 / 19$ & $32 / 5869$ & $51 / 5387$ \\
\hline 29 & 1 & $1 / 05$ & $0 / 32$ & $32 / 5854$ & $51 / 5362$ \\
\hline 30 & $0 / 13$ & $0 / 09$ & 0/06 & $32 / 5866$ & $51 / 5375$ \\
\hline 31 & $0 / 22$ & $0 / 07$ & $0 / 1$ & $32 / 586$ & $51 / 5355$ \\
\hline 32 & $0 / 36$ & $0 / 14$ & $0 / 17$ & $32 / 5854$ & $51 / 534$ \\
\hline 33 & $4 / 65$ & $2 / 53$ & $2 / 06$ & $32 / 5731$ & $51 / 5267$ \\
\hline 34 & $0 / 86$ & $0 / 6$ & $0 / 41$ & $32 / 5777$ & $51 / 5267$ \\
\hline 35 & $1 / 01$ & $0 / 8$ & $0 / 44$ & $32 / 5687$ & $51 / 5206$ \\
\hline 36 & $3 / 06$ & $3 / 02$ & $1 / 24$ & $32 / 5662$ & $51 / 5223$ \\
\hline 37 & $0 / 97$ & 1 & $0 / 36$ & $32 / 5662$ & $51 / 5223$ \\
\hline 38 & $0 / 21$ & $0 / 2$ & $0 / 09$ & $32 / 5626$ & $51 / 5197$ \\
\hline 39 & $4 / 27$ & $2 / 09$ & $2 / 1$ & $32 / 6438$ & $51 / 5838$ \\
\hline 40 & $0 / 46$ & $0 / 24$ & $0 / 2$ & $32 / 6429$ & $51 / 5781$ \\
\hline 41 & $0 / 19$ & $0 / 9$ & $0 / 04$ & $32 / 6416$ & $51 / 5775$ \\
\hline 42 & $1 / 15$ & $0 / 86$ & $0 / 53$ & $32 / 6446$ & $51 / 5851$ \\
\hline 43 & $2 / 04$ & $1 / 27$ & $0 / 91$ & $32 / 6424$ & $51 / 5945$ \\
\hline 44 & $0 / 29$ & $0 / 25$ & $0 / 13$ & $32 / 6429$ & $51 / 5898$ \\
\hline 45 & $0 / 53$ & $0 / 38$ & $0 / 25$ & $32 / 6434$ & $51 / 5917$ \\
\hline 46 & $0 / 66$ & $0 / 53$ & $0 / 3$ & $32 / 6394$ & $51 / 6023$ \\
\hline 47 & $0 / 81$ & $0 / 41$ & $0 / 4$ & $32 / 6398$ & $51 / 6053$ \\
\hline 48 & $0 / 94$ & $0 / 61$ & $0 / 42$ & $32 / 6402$ & $51 / 6078$ \\
\hline 49 & $0 / 53$ & $0 / 44$ & $0 / 23$ & $32 / 6373$ & $51 / 6354$ \\
\hline 50 & $0 / 4$ & $0 / 22$ & $0 / 16$ & $32 / 6393$ & $51 / 6369$ \\
\hline 51 & $0 / 35$ & $0 / 23$ & $0 / 14$ & $32 / 6399$ & $51 / 638$ \\
\hline
\end{tabular}

Appendix B. Descriptive statistics of $N$ removal by Aianthus altissima in three time periods

\begin{tabular}{c|c|c|c|c}
\hline Time & Concentration & Mean & Std. deviation & N \\
\hline \multirow{4}{*}{4 months } & $50 \mathrm{mg} \mathrm{L}^{-1}$ & 20.0901 & .03499 & 3 \\
& $10 \mathrm{mg} \mathrm{L}^{-1}$ & 4.9536 & .15663 & 3 \\
& $5 \mathrm{mg} \mathrm{L}^{-1}$ & 2.5430 & .08154 & 3 \\
& Total & 9.1956 & 8.23779 & 3 \\
\hline \multirow{5}{*}{5 months } & $50 \mathrm{mg} \mathrm{L}^{-1}$ & 18.3067 & .33262 & 3 \\
& $10 \mathrm{mg} \mathrm{L}^{-1}$ & 4.5200 & .09849 & 3 \\
& $5 \mathrm{mg} \mathrm{L}^{-1}$ & 2.0300 & .07211 & 9 \\
\hline \multirow{5}{*}{6 months } & Total & 8.2856 & 7.59484 & 3 \\
& $50 \mathrm{mg} \mathrm{L}^{-1}$ & 15.1933 & .16803 & 3 \\
& $10 \mathrm{mg} \mathrm{L}^{-1}$ & 4.2000 & .26458 & 9 \\
\hline \multirow{5}{*}{ Total } & $5 \mathrm{mg} \mathrm{L}^{-1}$ & 1.4000 & .10000 & 9 \\
& Total & 6.9311 & 6.31631 & 9 \\
& $50 \mathrm{mg} \mathrm{L}^{-1}$ & 17.8634 & 2.15441 & 9 \\
& $10 \mathrm{mg} \mathrm{L}^{-1}$ & 4.5579 & .36517 & 27 \\
\hline
\end{tabular}


Appendix C. Descriptive statistics of $P$ removal by Aianthus altissima in three time periods

\begin{tabular}{|c|c|c|c|c|}
\hline Time & Concentration & Mean & Std. deviation & $\mathbf{N}$ \\
\hline \multirow{4}{*}{4 months } & $50 \mathrm{mg} \mathrm{L}^{-1}$ & 17.1867 & .16623 & 3 \\
\hline & $10 \mathrm{mg} \mathrm{L}^{-1}$ & 4.5633 & .22502 & 3 \\
\hline & $5 \mathrm{mg} \mathrm{L}^{-1}$ & 2.5900 & .14000 & 3 \\
\hline & Total & 8.1133 & 6.86022 & 9 \\
\hline \multirow{4}{*}{5 months } & $50 \mathrm{mg} \mathrm{L}^{-1}$ & 15.1767 & .25325 & 3 \\
\hline & $10 \mathrm{mg} \mathrm{L}^{-1}$ & 3.8167 & .17786 & 3 \\
\hline & $5 \mathrm{mg} \mathrm{L}^{-1}$ & 1.6467 & .12897 & 3 \\
\hline & Total & 6.8800 & 6.29528 & 9 \\
\hline \multirow{4}{*}{6 months } & $50 \mathrm{mg} \mathrm{L}^{-1}$ & 13.3233 & .30436 & 3 \\
\hline & $10 \mathrm{mg} \mathrm{L}^{-1}$ & 2.7667 & .28746 & 3 \\
\hline & $5 \mathrm{mg} \mathrm{L}^{-1}$ & .8967 & .05033 & 3 \\
\hline & Total & 5.6622 & 5.80644 & 9 \\
\hline \multirow{4}{*}{ Total } & $50 \mathrm{mg} \mathrm{L}^{-1}$ & 15.2289 & 1.68705 & 9 \\
\hline & $10 \mathrm{mg} \mathrm{L}^{-1}$ & 3.7156 & .80761 & 9 \\
\hline & $5 \mathrm{mg} \mathrm{L}^{-1}$ & 1.7111 & .74139 & 9 \\
\hline & Total & 6.8852 & 6.17158 & 27 \\
\hline
\end{tabular}

Appendix D. Descriptive statistics of $N$ removal by Fraxinus rotundifolia in three time periods

\begin{tabular}{c|c|c|c|c}
\hline Time & Concentration & Mean & Std. deviation & N \\
\hline \multirow{4}{*}{4 months } & $50 \mathrm{mg} \mathrm{L}^{-1}$ & 16.0300 & .16823 & 3 \\
& $10 \mathrm{mg} \mathrm{L}^{-1}$ & 3.8695 & .05367 & 3 \\
& $5 \mathrm{mg} \mathrm{L}^{-1}$ & 2.0955 & .09425 & 3 \\
& Total & 7.3317 & 6.56958 & 9 \\
\hline \multirow{5}{*}{5 months } & $50 \mathrm{mg} \mathrm{L}^{-1}$ & 14.2867 & .07767 & 3 \\
& $10 \mathrm{mg} \mathrm{L}^{-1}$ & 2.6533 & .05508 & 3 \\
& $5 \mathrm{mg} \mathrm{L}^{-1}$ & 1.6167 & .12014 & 9 \\
\hline \multirow{5}{*}{6 months } & Total & 6.1856 & 6.09288 & 3 \\
& $50 \mathrm{mg} \mathrm{L}^{-1}$ & 13.3333 & .25166 & 3 \\
& $10 \mathrm{mg} \mathrm{L}^{-1}$ & 2.4667 & .05774 & 9 \\
\hline \multirow{3}{*}{ Total } & $5 \mathrm{mg} \mathrm{L}^{-1}$ & 1.0970 & .07515 & 9 \\
& Total & 5.6323 & 5.80768 & 9 \\
& $50 \mathrm{mg} \mathrm{L}^{-1}$ & 14.5500 & 1.19454 & 9 \\
& $10 \mathrm{mg} \mathrm{L}^{-1}$ & 2.9965 & .66149 & 27 \\
\hline
\end{tabular}

Appendix E. Descriptive statistics of P removal by Fraxinus rotundifolia in three time periods

\begin{tabular}{c|c|c|c|c}
\hline Time & Concentration & Mean & Std. deviation & N \\
\hline \multirow{3}{*}{4 months } & $50 \mathrm{mg} \mathrm{L}^{-1}$ & 16.4333 & .08622 & 3 \\
& $10 \mathrm{mg} \mathrm{L}^{-1}$ & 4.0253 & .02397 & 3 \\
& $5 \mathrm{mg} \mathrm{L}^{-1}$ & 2.5833 & .20232 & 3 \\
& Total & 7.6807 & 6.59506 & 9 \\
\hline \multirow{3}{*}{5 months } & $50 \mathrm{mg} \mathrm{L}^{-1}$ & 15.3633 & .16653 & 3 \\
& $10 \mathrm{mg} \mathrm{L}^{-1}$ & 3.4533 & .05508 & 3 \\
& $5 \mathrm{mg} \mathrm{L}^{-1}$ & 1.9500 & .06000 & 9 \\
\hline \multirow{5}{*}{6 months } & Total & 6.9222 & 6.36489 & 3 \\
& $50 \mathrm{mg} \mathrm{L}^{-1}$ & 14.3967 & .08622 & 3 \\
& $10 \mathrm{mg} \mathrm{L}^{-1}$ & 3.0000 & .04359 & 3 \\
& $5 \mathrm{mg} \mathrm{L}^{-1}$ & 1.0460 & .05011 & 9 \\
\hline \multirow{2}{*}{ Total } & Total & 6.1476 & 6.24466 & 9 \\
& $50 \mathrm{mg} \mathrm{L}^{-1}$ & 15.3978 & .88830 & 9 \\
& $10 \mathrm{mg} \mathrm{L}^{-1}$ & 3.4929 & .44652 & 9 \\
& $5 \mathrm{mg} \mathrm{L}^{-1}$ & 1.8598 & .67785 & 9 \\
\end{tabular}


Appendix $\boldsymbol{F}$. Descriptive statistics of $N$ removal by soil in three time periods

\begin{tabular}{|c|c|c|c|c|}
\hline Time & Concentration & Mean & Std. deviation & $\mathbf{N}$ \\
\hline \multirow{4}{*}{4 months } & $50 \mathrm{mg} \mathrm{L}^{-1}$ & 40.5748 & .40448 & 3 \\
\hline & $10 \mathrm{mg} \mathrm{L}^{-1}$ & 8.3589 & .32265 & 3 \\
\hline & $5 \mathrm{mg} \mathrm{L}^{-1}$ & 4.3858 & .09633 & 3 \\
\hline & Total & 17.7731 & 17.18955 & 9 \\
\hline \multirow{4}{*}{5 months } & $50 \mathrm{mg} \mathrm{L}^{-1}$ & 37.5933 & .46972 & 3 \\
\hline & $10 \mathrm{mg} \mathrm{L}^{-1}$ & 7.0567 & .05033 & 3 \\
\hline & $5 \mathrm{mg} \mathrm{L}^{-1}$ & 4.0667 & .05033 & 3 \\
\hline & Total & 16.2389 & 16.06984 & 9 \\
\hline \multirow{4}{*}{6 months } & $50 \mathrm{mg} \mathrm{L}^{-1}$ & 34.6667 & .57735 & 3 \\
\hline & $10 \mathrm{mg} \mathrm{L}^{-1}$ & 6.6000 & .26458 & 3 \\
\hline & $5 \mathrm{mg} \mathrm{L}^{-1}$ & 3.7800 & .02646 & 3 \\
\hline & Total & 15.0156 & 14.79225 & 9 \\
\hline \multirow{4}{*}{ Total } & $50 \mathrm{mg} \mathrm{L}^{-1}$ & 37.6116 & 2.59314 & 9 \\
\hline & $10 \mathrm{mg} \mathrm{L}^{-1}$ & 7.3385 & .81786 & 9 \\
\hline & $5 \mathrm{mg} \mathrm{L}^{-1}$ & 4.0775 & .26834 & 9 \\
\hline & Total & 16.3425 & 15.46038 & 27 \\
\hline
\end{tabular}

Appendix G. Descriptive statistics of P removal by soil in three time periods

\begin{tabular}{|c|c|c|c|c|}
\hline Time & Concentration & Mean & Std. deviation & $\mathbf{N}$ \\
\hline \multirow{4}{*}{4 months } & $50 \mathrm{mg} \mathrm{L}^{-1}$ & 40.0833 & .60575 & 3 \\
\hline & $10 \mathrm{mg} \mathrm{L}^{-1}$ & 7.1567 & .14844 & 3 \\
\hline & $5 \mathrm{mg} \mathrm{L}^{-1}$ & 4.3467 & .14572 & 3 \\
\hline & Total & 17.1956 & 17.21188 & 9 \\
\hline \multirow{4}{*}{5 months } & $50 \mathrm{mg} \mathrm{L}^{-1}$ & 37.0267 & .08622 & 3 \\
\hline & $10 \mathrm{mg} \mathrm{L}^{-1}$ & 6.4233 & .56012 & 3 \\
\hline & $5 \mathrm{mg} \mathrm{L}^{-1}$ & 3.6900 & .41869 & 3 \\
\hline & Total & 15.7133 & 16.03263 & 9 \\
\hline \multirow{4}{*}{6 months } & $50 \mathrm{mg} \mathrm{L}^{-1}$ & 34.0367 & .46199 & 3 \\
\hline & $10 \mathrm{mg} \mathrm{L}^{-1}$ & 5.4533 & .28572 & 3 \\
\hline & $5 \mathrm{mg} \mathrm{L}^{-1}$ & 3.2700 & .17349 & 3 \\
\hline & Total & 14.2533 & 14.87032 & 9 \\
\hline \multirow{4}{*}{ Total } & $50 \mathrm{mg} \mathrm{L}^{-1}$ & 37.0489 & 2.64625 & 9 \\
\hline & $10 \mathrm{mg} \mathrm{L}^{-1}$ & 6.3444 & .80737 & 9 \\
\hline & $5 \mathrm{mg} \mathrm{L}^{-1}$ & 3.7689 & .52679 & 9 \\
\hline & Total & 15.7207 & 15.48488 & 27 \\
\hline
\end{tabular}

